\title{
Virulent Race Overcome Wheat Stem Rust Resistance Gene Sr27 in Egypt
}

M.A. Hasan

Wheat Dis. Res. Dept., Plant Pathol. Res. Inst., ARC, Giza, Egypt.

$\mathbf{T}$

Triticale is an excellent source of resistance to wheat stem rust, caused by Puccinia graminis f.sp. tritici. Stem rust historically is one of the most destructive diseases of wheat (Triticum aestivum L.) worldwide. Deployment of resistant genotypes successfully prevented rust epidemics over the past several decades. This is primarily due to the on-going incorporation of effective stem rust resistance genes into new wheat breeding materials; this may place the pathogen under great selection pressure. Although $5 r 27$ has little effect on the commercial wheat production, it has a major impact on the commercial triticale cultivars. In Egypt, high levels of stem rust infection were observed on wheat cultivar (Cooring) which carrying Sr27 grown at Gemmiza Research Station during May 2015. Samples collected from rusted stems of wheat cultivar (Cooring) were cut and artificially inoculated on primary leaves of 8-day-old seedlings of highly susceptible wheat $\mathrm{Cv}$. Morocco. Four single pustules were collected and race analysis was done. Results showed that out of the four identified races, race QQQCM was the most virulent one on wheat seedling carrying $\mathrm{Sr} 27$ with infection type (4), whereas the rest of races were a virulent to $S r 27$. This race (QQQCM) first time to appear in Egypt from previous identified races. Regarding to the performance of 20 stem rust resistant genes at seedling stage, ( $\mathrm{Sr}$ 9e,7b,8a,9g,30,17,9a,9d,10,31and $S r 38$ ) were resistant to race QQQCM, meanwhile the rest Srs were susceptible.

Keywords: Puccinia graminis f.sp. tritici, resistant genes, stem rust, Triticum aestivum $\mathrm{L}$. and wheat.

Stem rust of wheat caused by the fungus Puccinia graminis Pers. f.sp. tritici Eriks. \& E.Henn. is the most destructive disease on wheat worldwide. Successful control of the disease over three decades through the use of genetic resistance has resulted in a sharp decline in research activity in recent years (El-Daoudi, et al., 1995). Occurrence of new races in a geographic/ epidemiologic regions can be attributed to the migration from an outside such as spread of race TTKS, in East Africa commonly known as Ug99 to anther countries (Singh et al., 2006). Wheat stem rust resistant gene $\operatorname{Sr} 27$ (3A.3R translocation) is one of the most important gene possess resistant to stem rust especially in triticale, whereas virulence on $\mathrm{Sr} 27$ is rare. Acosta (1962) and Harder et al. (1972) isolated an east African culture virulent on Pembina line with Sr27. McIntosh (1983) showed that isolates of $P$. graminis f.sp. tritici from triticale cv. Coorong were virulent on wheat seedlings with $\operatorname{Sr} 27$. The results were accepted as evidence that the resistance gene in Coorong and many other triticale lines developed in Mexico was $\mathrm{Sr} 27$. Virulence on triticale genotypes with $\mathrm{Sr} 27$ was found in South Africa in 1988. Smith and Le Roux (1992) and McIntosh (1983) stated that Sr27 occurred at high frequency in lines present in 
nurseries distributed from CIMMYT and gave warning of genetic vulnerability. The value of adult plant resistance in protecting wheat genotypes against such virulent stem rust races could be achieved by combining many genes of resistance in single genotypes that conferred high level of generalized resistance against the pathogens. In this respect, Brennan and Murray (1988) stated that a breeding program should develop rust resistant cultivars conditioned with resistance genes (both race- specific and race- nonspecific resistance). The inheritance of adult plant resistance has often been considered as a complex, but there is an evidence also that it is oligogenic (Barcellos et al., 2000). The identification of genes conferring stem rust adult plant resistance would be a significant step towards a good control of such disease (Manninger et al., 1998; Nazim et al., 2001 and Mousa et al., 2004).

The objective of this study was to identify and characterize the new race that overcome the resistant gene $\mathrm{Sr} 27$ which governing the resistance in triticale.

\section{Materials and Methods}

Collected samples from the infected wheat genotypes Coorong carrying $\mathrm{Sr} 27$ were used to identify physiologic race(s) that overcome the resistance of $S r 27$. The collected samples (rusted stems) were kept in glassine envelopes (8 x $15 \mathrm{~cm})$. Rust samples, were left at room temperature for 24 hours to remove the humidity in the samples. After that samples were preserved in dissector in fridge until usage. The infected specimens were transferred to the very susceptible wheat cv. Morocco. The method of inoculation was carried out as described by Stakman et al. (1962). Eight days old seedlings were sprayed with an atomizer in the inoculation chambers with water then inoculated by shaking and brushing rusted materials over the plants and sprayed gently again with water in order to induce "dew" on the plant. Finally, the inoculated plants were kept in damp chambers for 24 hours to allow the rust spores to germinate and cause infection. Inoculated plants were transferred and placed on benches in the greenhouse and kept for 14 day. After developing the rust symptoms, four single pustules were separately isolated from the sample and inoculated again on very susceptible wheat cultivar seedlings Morocco to obtain enough urediospores to inoculate the differential sets.

Infection types (IT) were scored after 14 days using the 0-4 scale of Stakman et al. (1962). Infection types were categorized as either being Low (resistant 0, 0; 1 and 2) or High (susceptible 3 and 4). The differential host series consisted of wheat rust monogenic lines, arranged in five subsets (Table 1). Races were assigned using the international Pgt-code as suggested by Roelfs and Martens (1988).

\section{R e s u l t s}

Race analysis from the infected wheat triticale Cooring (Fig. 1and 2) showed that four races were identified based on their reaction on 20 differential sets listed on Table (1). Most of the identified races varied in their virulence on stem rust resistance gene $S r 27$, this indicated a high level of variation both in quantity and virulence spectrum. The obtained data (Table 2 and 3), revealed that the identified races possess different infection types on $\mathrm{Sr} 27$ ranged from (0, to 4). Race QQQCM 

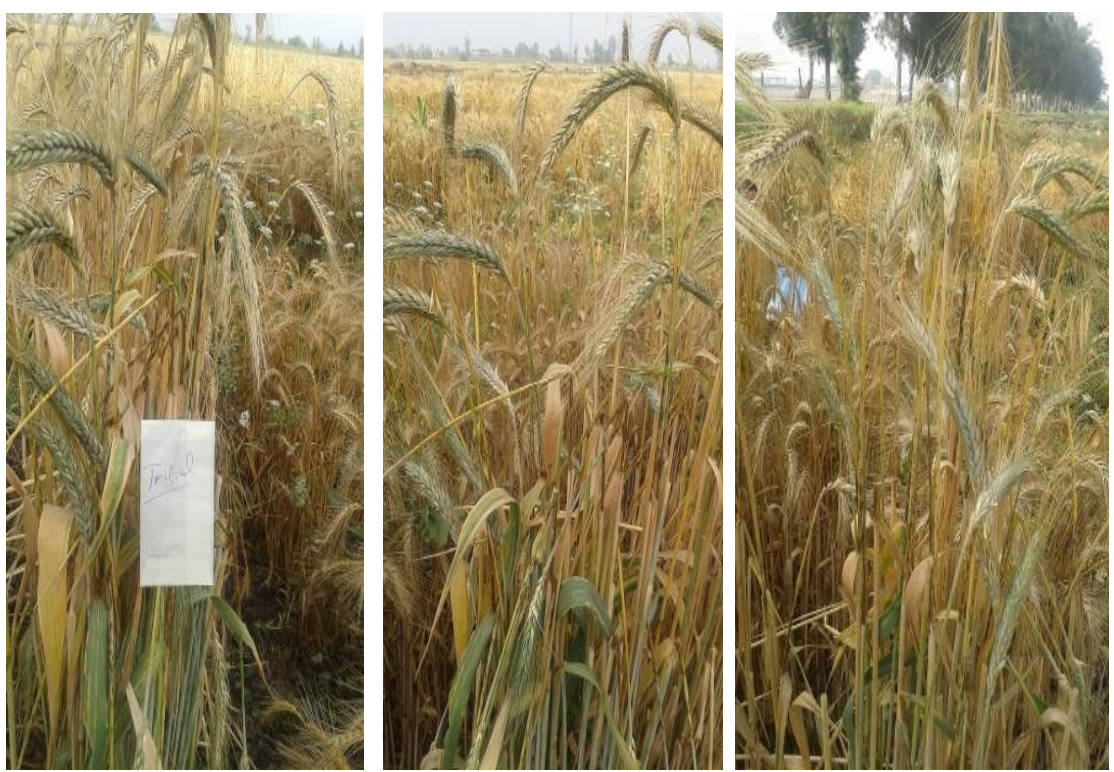

Fig. 1. Infected wheat triticale Cooring with Sr27 at Gemmiza Research Station-during May 2015.
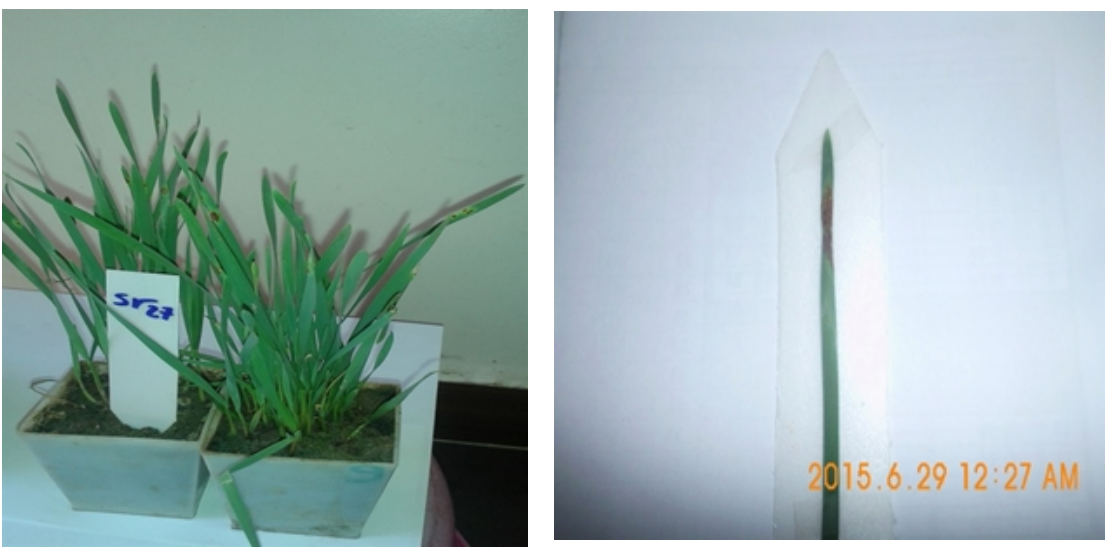

Fig. 2. Virulent race overcome wheat stem rust resistance gene Sr27 in Egypt.

was the virulent one on $\mathrm{Sr} 27$ which gave susceptible reaction with infection type (4), meanwhile the rest races showed a virulent infection types $(0,-1-2)$. On the other hand, race KKBBB was less aggressive on the differential sets which overcome the resistance of six stem rust resistant genes ( $\mathrm{Sr} 21,9 e, 7 b, 6,8 a$ and $\mathrm{Sr} 9 \mathrm{~g}$ ). Races TTMCC and BCPPL were intermediate in their effect on the resistant genes. 
Table 1. Pgt-code races of Puccinia graminis f.sp. tritici

\begin{tabular}{|c|c|c|c|c|c|}
\hline \multirow[b]{2}{*}{$\begin{array}{l}\overrightarrow{0} \\
\text { ô } \\
\vec{\Xi} \\
\vec{s}\end{array}$} & \multicolumn{5}{|c|}{ Infection types produced on host lines with $\mathrm{Sr}$} \\
\hline & $\begin{array}{l}1 \\
2 \\
3 \\
4 \\
5\end{array}$ & $\begin{array}{l}5 \\
11 \\
36 \\
9 a \\
24\end{array}$ & $\begin{array}{c}21 \\
6 \\
9 b \\
9 d \\
31\end{array}$ & $\begin{array}{l}9 e \\
8 a \\
30 \\
10 \\
38\end{array}$ & $\begin{array}{c}7 b \\
9 g \\
17 \\
T m p \\
M C N\end{array}$ \\
\hline $\begin{array}{l}0 \\
\frac{0}{0} \\
0 \\
\frac{1}{00} \\
0\end{array}$ & $\begin{array}{c}\text { B } \\
\text { C } \\
\text { D } \\
\text { F } \\
\text { G } \\
\text { H } \\
\text { J } \\
\text { K } \\
\text { L } \\
\text { M } \\
\text { N } \\
\text { P } \\
\text { Q } \\
\text { R } \\
\text { S } \\
\text { T }\end{array}$ & $\begin{array}{l}\text { Low } \\
\text { Low } \\
\text { Low } \\
\text { Low } \\
\text { Low } \\
\text { Low } \\
\text { Low } \\
\text { Low } \\
\text { High } \\
\text { High } \\
\text { High } \\
\text { High } \\
\text { High } \\
\text { High } \\
\text { High } \\
\text { High }\end{array}$ & $\begin{array}{l}\text { Low } \\
\text { Low } \\
\text { Low } \\
\text { Low } \\
\text { High } \\
\text { High } \\
\text { High } \\
\text { High } \\
\text { Low } \\
\text { Low } \\
\text { Low } \\
\text { Low } \\
\text { High } \\
\text { High } \\
\text { High } \\
\text { High }\end{array}$ & $\begin{array}{l}\text { Low } \\
\text { Low } \\
\text { High } \\
\text { High } \\
\text { Low } \\
\text { Low } \\
\text { High } \\
\text { High } \\
\text { Low } \\
\text { Low } \\
\text { High } \\
\text { High } \\
\text { Low } \\
\text { Low } \\
\text { High } \\
\text { High }\end{array}$ & $\begin{array}{l}\text { Low } \\
\text { High } \\
\text { Low } \\
\text { High } \\
\text { Low } \\
\text { High } \\
\text { Low } \\
\text { High } \\
\text { Low } \\
\text { High } \\
\text { Low } \\
\text { High } \\
\text { Low } \\
\text { High } \\
\text { Low } \\
\text { High }\end{array}$ \\
\hline
\end{tabular}

Table 2. Infection type produced on $\mathrm{Sr} 27$ with the identified races

\begin{tabular}{|c|c|c|c|c|c|}
\hline No. & Race & I.T & No. & Race & I.T \\
\hline 1 & QQQCM & 4 & 3 & BCPPL & 2 \\
\hline 2 & TTMCC & 0 & 4 & KKBBB & 1 \\
\hline
\end{tabular}

Concerning a virulence/virulence formulae of data presented in Table (4) race QQQCM was the virulent one on $\mathrm{Sr} 27$ and nine stem rust resistant genes, i.e. (Sr5,21,11,6,36,9b, TMP, 24 and $\mathrm{SrMcN})$. On the other hand race KKBBB was less aggressive on stem rust resistant genes which showed virulence on six stem rust resistant genes $(\mathrm{Sr} 21,9 \mathrm{e}, 7 \mathrm{~b}, 6,8 \mathrm{a}$ and 9g), meanwhile it was a virulent on $\mathrm{Sr} 27$. Races TTMCC and BCPPL were a virulent on Sr27and virulent on different stem rust resistant genes.

Effectiveness of stem rust resistant genes was assessed. Sr31 and $\mathrm{Sr} 38$ were completely effective to all identified races whereas $\mathrm{Sr} 9 \mathrm{~g}$, $\mathrm{Sr} 36$ and SrTMP were the least effective.

Egypt. J. Phytopathol., Vol. 43, No. 1-2 (2015) 
Table 3. Infection types of twenty differential lines in addition to $\mathbf{S r 2 7}$ inoculated with four single pustules

\begin{tabular}{|c|c|c|c|c|c|}
\hline \multirow{2}{*}{ Set } & \multirow{2}{*}{ Sr genes } & \multicolumn{4}{|c|}{ Infection type / Single pustules } \\
\hline & & 1 & 2 & 3 & 4 \\
\hline \multicolumn{6}{|l|}{ Set 1} \\
\hline 1 & $\operatorname{Sr} 5$ & $\mathrm{H}$ & $\mathrm{H}$ & $\mathrm{L}$ & $\mathrm{L}$ \\
\hline 2 & $S r 21$ & $\mathrm{H}$ & $\mathrm{H}$ & $\mathrm{L}$ & $\mathrm{H}$ \\
\hline 3 & Sr9e & $\mathrm{L}$ & $\mathrm{H}$ & $\mathrm{L}$ & $\mathrm{H}$ \\
\hline 4 & $S r 7 b$ & $\mathrm{~L}$ & $\mathrm{H}$ & $\mathrm{L}$ & $\mathrm{H}$ \\
\hline \multicolumn{6}{|l|}{ Set 2} \\
\hline 1 & Sr11 & $\mathrm{H}$ & $\mathrm{H}$ & $\overline{\mathrm{L}}$ & $\bar{L}$ \\
\hline 2 & Sr6 & $\mathrm{H}$ & $\mathrm{H}$ & $\mathrm{L}$ & $\mathrm{H}$ \\
\hline 3 & Sr8a & $\mathrm{L}$ & $\mathrm{H}$ & $\mathrm{L}$ & $\mathrm{H}$ \\
\hline 4 & $\operatorname{Sr9g}$ & $\mathrm{L}$ & $\mathrm{H}$ & $\mathrm{H}$ & $\mathrm{H}$ \\
\hline \multicolumn{6}{|l|}{ Set 3} \\
\hline 1 & Sr36 & $\mathrm{H}$ & $\mathrm{H}$ & $\mathrm{H}$ & $\mathrm{L}$ \\
\hline 2 & $\mathrm{Sr} 9 b$ & $\mathrm{H}$ & $\mathrm{L}$ & $\mathrm{L}$ & $\mathrm{L}$ \\
\hline 3 & Sr30 & $\mathrm{L}$ & $\mathrm{L}$ & $\mathrm{H}$ & $\mathrm{L}$ \\
\hline 4 & Sr17 & $\mathrm{L}$ & $\mathrm{H}$ & $\mathrm{H}$ & $\mathrm{L}$ \\
\hline \multicolumn{6}{|l|}{ Set 4} \\
\hline 1 & Sr9a & $\mathrm{L}$ & $\mathrm{L}$ & $\mathrm{H}$ & $\mathrm{L}$ \\
\hline 2 & Sr9d & $\mathrm{L}$ & $\mathrm{L}$ & $\mathrm{L}$ & $\mathrm{L}$ \\
\hline 3 & Sr10 & $\mathrm{L}$ & $\mathrm{L}$ & $\mathrm{H}$ & $\mathrm{L}$ \\
\hline 4 & SrTMP & $\mathrm{H}$ & $\mathrm{H}$ & $\mathrm{H}$ & $\mathrm{L}$ \\
\hline \multicolumn{6}{|l|}{ Set 5} \\
\hline 1 & Sr24 & $\mathrm{H}$ & $\mathrm{L}$ & $\mathrm{H}$ & $\mathrm{L}$ \\
\hline 2 & Sr31 & $\mathrm{L}$ & $\mathrm{L}$ & $\mathrm{L}$ & $\mathrm{L}$ \\
\hline 3 & Sr38 & $\mathrm{L}$ & $\mathrm{L}$ & $\mathrm{L}$ & $\mathrm{L}$ \\
\hline \multirow[t]{2}{*}{4} & $S r M c N$ & $\mathrm{H}$ & $\mathrm{H}$ & $\mathrm{L}$ & $\mathrm{L}$ \\
\hline & Sr 27 & $\mathrm{H}$ & $\mathrm{L}$ & $\mathrm{L}$ & $\mathrm{L}$ \\
\hline Race & & QQQCM & TTMCC & BCPPL & KKBBB \\
\hline
\end{tabular}

Table 4. A virulence/Virulence pattern of identified races

\begin{tabular}{|c|l|l|}
\hline No. & \multicolumn{1}{|c|}{ Race } & \multicolumn{1}{c|}{ Avirulence / Virulence genes } \\
\hline 1 & QQQCM & Sr9e,7b,8a,9g,30,17,9a,9d,10,31,38/ \\
\hline 2 & TTMCC & Sr9b,30,9a,9d, 10,24,31,38,27/ \\
\hline 3 & BCPPL & Sr5, 21, 9e, 7b; 11, 6, 8a, Sr9b,9d,31,38,McN,27/ \\
\hline 4 & KKBBB & Sr5,11,36,9b,30,17,9a,9d,10,TMP,24, 31,38,McN,27/ \\
\hline
\end{tabular}




\section{Dis c us s i on}

Wheat stem rust is the most important disease of wheat all over the world. The pathogen is able to produce new races that can attack previously resistant varieties and develop rapidly under optimal environmental conditions which results in a serious yield loss. Hence, monitoring the disease and its races is of great importance for sustainable wheat management programs. Race analysis of samples collected from wheat triticale (Cooring) which carrying $S r 27$, revealed that race QQQCM was the virulent one on $\mathrm{Sr} 27$, meanwhile the rest races were a virulent. Race QQQCM showed high infection type (4) on some important stem rust genes, i.e. Sr36, Sr24 and SrMcN. In this respect, McIntosh (1983) stated that isolates of Puccinia graminis f.sp. tritici from triticale cv. Coorong were virulent on wheat seedlings with $S r 27$. Also, they found that $S r 27$ occurred at high frequency in lines present in nurseries distributed from CIMMYT. Olivera et al. (2013) reported that three South African $P$. graminis f.sp. tritici isolates UVPgt53, UVPgt56 and UVPgt57 were virulent on $\mathrm{Sr} 27$. They stated that these isolates were virulent on 8 stem rust resistant genes Sr8a, 9a, 9b, 9d, 9g, 10, 11and McN.

\section{References}

Acosta, A.C. 1962. The transfer of stem rust resistance from rye to wheat. Dis. Abstr., 23: 34-35.

Barcellos, A.L.; Roelfs, A. P. and de Moraes-Fernands, M.I.B. 2000. Inheritance of adult plant leaf rust resistance in the Brazilian cultivars Toropi. Plant Dis., 84: 90-93.

Brennan, J.P. and G.M. Murray. 1988. Australian wheat diseases assessing their economic importance. Agric. Sci. (New Series), 1: 26-35.

Harder, D.E.; Mathenge, G.R. and Mwaura, L.K. 1972. Physiologic specialization and epidemiology of wheat stem rust in east Africa. Phytopathology, 62: 166-171.

El-Daoudi, Y.H.; Mamluk, O.F.; Abu El-Naga, S.A.; Ahmed, M.S.; Bekele, E.; El-Sherif, Nabila A. and Khalifa, M.O. 1995. Virulence survey of Puccinia graminis f.sp. tritici and genes conferring resistance to wheat stem rust in the Nile Valley countries, Yemen and Syria during 1992/93 and 1993/94. Egypt. J. Appl. Sci., 11(3): 90-110.

McIntosh, R.A.1983. Induced mutations of rust resistance genes in wheat. Pages: 115-118. In: Induced Mutations for Disease Resistance in Crop Plants $I I^{\prime}$. International Atomic Energy Agency, Vienna.

Manninger, K.; Sosz, M.C.; Falusi, J. and Mesterhazy, A. 1998. Postulation resistance genes to wheat stem rust in winter wheat genotypes from Szeged. Acta Phytopathol. Entomol., 33: 37-42.

Mousa, M.M.; Najeeb, M.A.; Boulot, O.A. and Youssef, W.A. 2004. Probable genes for stem rust resistance in some Egyptian wheat varieties. Egypt. J. Appl. Sci., 19: 151-163.

Egypt. J. Phytopathol., Vol. 43, No. 1-2 (2015) 
Nazim, M.S.; Awad, M.A.; Boulot, O.A.; Abu El-Naga, S.A. and Abdel Hamid, I. 2001. Durable resistance to stem rust in some Egyptian wheat cultivars. Mun. J. Agric. Res., 26(6): 1485-1499.

Olivera, P.D.; Pretorius, Z.A.; Badebo, A.; and Jin, Y. 2013. Identification of resistance to races of Puccinia graminis f.sp. tritici with broad virulence in triticale (x Triticosecale). Plant Dis., 97: 479-484.

Roelfs, A.P. and Martens, J.W. 1988. An international system of nomenclature for Puccinia graminis f.sp. tritici. Phytopathology., 78(5): 526-533.

Smith, J. and Le Roux, J. 1992. First report of wheat stem rust virulence for Sr27 in South Africa. Vorträge für Pflanzenzüchtung, 24: 109-110.

Singh, R.P.; Hodson, D.P.; Jin, Y.; Huerta-Espino, J.; Kinyua, M.G.; Wanyera R.; Njau, P. and Ward, R.W. 2006 Current status, likely migration and strategies to mitigate the threat to wheat production from race Ug99 (TTKS). CAB Reviews: Perspectives in Agric., Veterinary Sci., Nutrition and Natural Resources, 1(54): 1-13.

Stakman, E.C.; Stewart, D.M. and Loegering, W.Q. 1962. Identification of physiological races of Puccinia graminis var. tritici USDA-ARS. Bull, E617. U.S. Dept. Agric., Agric. Res. Service, Print Office, Washington DC. 54pp.

(Received 30/11/2015; in revised form 31/12/2015) 
سلالة شديدة القدرة المرضية كسرت جين

(Sr 27)

ـ معهد بحوث امر اض النباتات ـ مركز البحوث الزر اعيةـ

محمد عبد القادر حسن

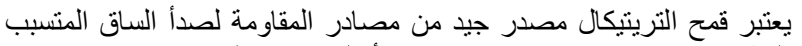

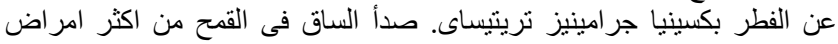

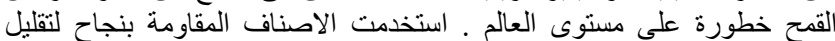

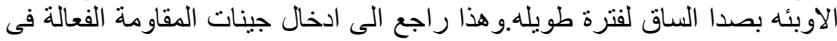

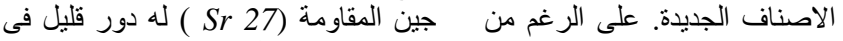

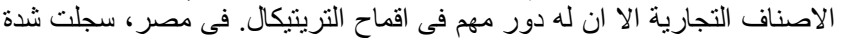

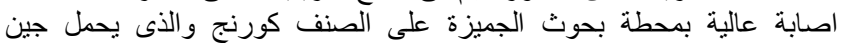

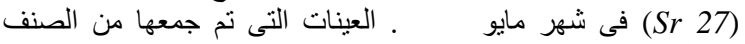

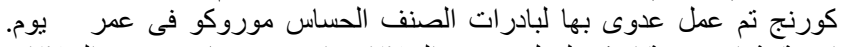

اربعة بثر ات فردية اخذت لعمل تعريف السلالات. اوضحت لنات نتائج تعريف السلالات

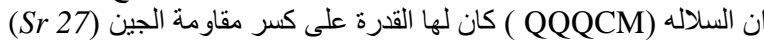

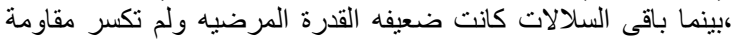

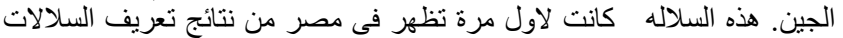

السابقة . فيما يخص كفاءة الجينات فى طور البادرة كانت الجينات (8)

(8a,9g, 30, 17, 9a, 9d, 10, 31 and 38

بينما باقى الجينات كانت حساسة للاصابة. 